Journal of Environmental Sciences (JES)

Faculty of Graduate Studies and Environmental Research, Ain Shams University

Ali, Hoda., et al.

\title{
PRODUCING OF SOME DERIVATIVES OF CELLULOSE BY RECYCLING OF PAPER AND AGRICULTURAL
}

\section{WASTES}

\author{
Hoda A. M. Ali ${ }^{(1)}$;Mohamed Y. Elkadi(2); Nabil M. Amin ${ }^{(3)}$ \\ and Fatma A. Mahmoud ${ }^{(4)}$
}

1) Post Grad Student, Faculty of Graduate Studies and Environmental Research, Ain Shams University 2) Faculty of Science, Ain Shams University, Cairo, Egypt 3) Ministry of Manpower and Migration, Cairo, Egypt 4) Researcher at National Research Center, Giza, Egypt

\begin{abstract}
The world now is looking for renewable, cheap alternatives to be used in industry to save the environment for sustainable life and the money for the factory's owners. This research is dealing with the possibility of synthesizing nitrocellulose (NC) from an easily renewable agriculture waste such as bagasse, is demonstrated in extraction of $\alpha$-cellulose, by pulping, bleaching, and nitration, were found nitrocellulose with nitrogen content ranged from (less than 7.0 to $11.4 \%$ ), and relative viscosity $1 \%$ from (1.09 to 4.44). The NC structure and fibers were characterized by analytical techniques such IR spectroscopy and proton NMR spectroscopy. It was found that the bagasse gives very good results when used to give nitrocellulose.
\end{abstract}

Keywords: alpha cellulose - nitrocellulose- bagasse.

\section{INTRODUCTION}

Continuation to our scholar researcher work the author enhance the economic value of agriculture wastes to minimize the pollution environmental impact of the open fire agriculture waste. (El Kady et al.,

\author{
Vol.(50); Iss.(10); No.(4); Oct. 2021 \\ ISSN $1110-0826$ \\ Online ISSN 2636-3178
}


2014; El Hoshaudy et al., 2015; El Kady et al., 2016 and Saleh et al., 2019).

The volume of the agricultural wastes (leaves, tree cuts, crop residues, husks or roots) is estimated by about 32-35 million tons per year (Abdel-Ala et al., 2003; Abou Hussein and Sawan 2010 and Bayoumi et al., 2014).

The misused of these agricultural wastes represents a dangerous environmental damage and a waste of an economic resource.

Agricultural wastes such as wheat straw, rice straw, bagasse, and cotton stalk are rich in lignocellulose and primarily contain cellulose, lignin, hemicellulose, and extractives (Khezami et al., 2005 and Stefanidis et al., 2014). Cellulose forms a skeleton that is surrounded by hemicellulose and lignin functioning as matrix and encrusting materials, respectively (Ingram and Doran 1995).

The environmental impact due to bagasse pulp production is more controlled Compared to rice straw pulping, due to the different chemical properties of the effluents. Although rice straw is available at a minimal cost, the economic effectiveness is relatively low due to unavailability of proven technology for chemical recovery of silica content from the resulting black liquor. Furthermore, a typical mill for soda or kraft pulp using bagasse in Egypt generates energy in the form of steam and electricity from recovery boilers (EEAA, 2003). 
Producing of some derivatives of cellulose by recycling of bagasse were done in our research by soda pulping mechanism.

We tried to close our work on the chosen raw materials to the way of handling the cotton linter in industry, to ease and faster the substitution of cotton linter by our chosen raw materials according to the results obtained.

Nitrocellulose (NC), is an important industrial polymer manufactured by nitrating the hydroxyl groups of cellulose. It has many applications, the nature of which depends on its degree of nitra tion or nitrogen content. At low nitrogen contents (below 12.2\%) it is used in cosmetics, printing inks, paints and lacquers, whereas at nitrogen contents above $12.2 \%$, it is used as an energetic ingredient in gun and rocket propellants. Moreover, NC has been used in a wide range of products including plastics, paints and lacquers, and smokeless gun propellants (Gismatulina et al., 2017).

The aim of the work is to produce cellulose and some of its derivatives such as nitocellulose from a renewable, cheap agriculture waaste alternatives such as bagaase.

\section{MATERIALS AND METHODS}

Materials: Sodium hydroxide, pellets, 98\%, Dae-Jung, reagents chemicals, Kosoaq, listed company, Hydrogen peroxide solution $30 \%, \mathrm{PDH}$ laboratory supplies pools, England, Diethyl ether, Abo Zaabal Company for specialized chemicals. Acetic acid (glacial, AR grade), Carbon group, Cork,

Vol.(50); Iss.(10); No.(4); Oct. 2021 
Ireland, Copper II ethylene diamine solution, PDH laboratory supplies, England, Ferric sulphate hydrate extra pure, assay as Fe 20\%, LOBA chemie, Acetone pure $99 \%$ produced by Abo zaabal company for specialized chemicals, Sulphuric acid 98\%, made in United Kingdom, Merck KGaA, Germany.

Preparation of the raw material: The stalks of bagasse were cut into small pieces ranged from $3.0-5.0 \mathrm{~cm}$, in some experiments the outside green bark was removed, and the stalks were grinded to fine powder.

Pulping process: Used alkaline pulping process which include the delignification of cellulosic fibers by alkaline sodium hydroxide concentration $17.5 \%$ (gm volume) in molar ratio $1: 5$ to $1: 10 \mathrm{gm}$ m.volume either by refluxing on water bath or by put in round glass equipped with water condenser refluxed from 4-9.5 hrs. with vigorous shaking from time to time, at the end of time filter the content in centery glass, washed with tab water, then distilled water till neutralization, finally washed by aqueous acetic acid to completely neutralize, then ethyl alcohol dry the content, gravimetrically estimate the yielding percent and stored into polyethylene bags to the next step process and easily removed the hemicellulose to convert the produced cellulose into fibers. 
Ali, Hoda., et al.

Table (1): preparing and pulping conditions of bagasse

\begin{tabular}{|c|c|c|}
\hline Exp. No. & Preparation conditions & Pulping conditions with $\mathrm{NaOH \%}$ \\
\hline 1 & $\begin{array}{c}\text { Cutted bagasse, bag in a water } \\
\text { bath }\end{array}$ & $\begin{array}{l}\text { (Wt. of sample: sod. Hydroxide } 17.5 \% 1: 10) \\
\text { for } 3.5 \text { hrs. Then renewing the soln. for } 2 \\
\text { more hrs. }\end{array}$ \\
\hline 2 & $\begin{array}{l}\text { Flatted, cut sample - on an oil } \\
\text { bath }\end{array}$ & $\begin{array}{l}\text { (Wt. of sample: sod. Hydroxide } 17.5 \% \text { 1:8) } \\
\text { for } 4 \mathrm{hrs.}\end{array}$ \\
\hline 3 & $\begin{array}{l}\text { Flatted, cut sample - on a } \\
\text { water bath }\end{array}$ & $\begin{array}{c}\text { (Wt. of sample: sod. Hydroxide } 17.5 \% \text { 1:8) } \\
\text { for } 5 \mathrm{hrs.}\end{array}$ \\
\hline 4 & $\begin{array}{l}\text { Flatted, cut sample - on a } \\
\text { water bath }\end{array}$ & $\begin{array}{l}\text { (Wt. of sample: sod. Hydroxide 17.5\%1:8) } \\
\text { for } 5 \text { hrs. }\end{array}$ \\
\hline 5 & $\begin{array}{l}\text { Debarked, cut sample, on a } \\
\text { water bath }\end{array}$ & $\begin{array}{l}\text { (Wt. of sample: sod. Hydroxide } 17.5 \% \text { 1:8) } \\
\text { for } 5 \mathrm{hrs.}\end{array}$ \\
\hline 6 & $\begin{array}{l}\text { Cut, grinding sample, on a } \\
\text { water bath }\end{array}$ & $\begin{array}{l}\text { (Wt. of sample: sod. Hydroxide } 17.5 \% 1: 8) \\
\text { for } 5 \mathrm{hrs.}\end{array}$ \\
\hline 7 & $\begin{array}{l}\text { Grinded barked, sample, on a } \\
\text { water bath }\end{array}$ & $\begin{array}{c}\text { (Wt. of sample: sod. Hydroxide } 17.5 \% \text { 1: 5) } \\
\text { for } 5 \mathrm{hrs} \text {. }\end{array}$ \\
\hline$\wedge$ & $\begin{array}{l}\text { the sample was debarked and } \\
\text { grinded, on a water bath }\end{array}$ & $\begin{array}{c}\text { (Wt. of sample: sod. Hydroxide } 17.5 \% \\
1: 10 \text { ) for } 9.5 \mathrm{hrs} \text {. }\end{array}$ \\
\hline
\end{tabular}

Treatment with $\mathrm{H}_{2} \mathrm{SO}_{4}$ : For some experiments, pulped bagasse was treated with aqueous sulphuric acid 1\% refluxing for 10 minutes, 20 minutes, 30 minutes and an hour. Determination of the loss content (weight of the sample, weight of the residue remained after treatment), comparing the $\alpha$ cellulose content.

This treatment to fibrate and increase the delignification to activate the raw materials towards nitration process.

In exp. no. (8), the pulped sample was divided into 5 groups, 4 of them treated with $1 \% \mathrm{H}_{2} \mathrm{SO}_{4}$. For different times, and the fifth processed normally

Vol.(50); Iss.(10); No.(4); Oct. 2021 
without adding $\mathrm{H}_{2} \mathrm{SO}_{4}$, exp.no. (8-b) gives the best results according to Wt. remains after adding $\mathrm{H} 2 \mathrm{SO} 4$, as shown below in table no. 2

Table (2): $\mathrm{H}_{2} \mathrm{SO}_{4}$ treatment conditions on pulped bagasse

\begin{tabular}{|c|c|c|}
\hline \hline Exp. No. & $\begin{array}{c}\mathbf{1 \%} \mathbf{H}_{2} \mathbf{S O}_{4} \text { treatment } \\
\text { conditions }\end{array}$ & $\begin{array}{c}\text { Wt. remains after adding } \\
\mathbf{H}_{2} \mathbf{S O}_{4} \text { only \% }\end{array}$ \\
\hline \hline 8-a & 10 min. On a water bath, & 84.2 \\
\hline 8-b & 20 min. On a water bath, & 86.0 \\
\hline 8-c & 30 min. On a water bath, & 81.4 \\
\hline 8-d & 1 hr. On a water bath & 81.8 \\
\hline 8-e & Without adding $\mathrm{H}_{2} \mathrm{SO}_{4}$ & \\
\hline
\end{tabular}

Bleaching: Selected pulp samples were bleached in 2 stages, The first stage proceeded by aqueous sodium hypochlorite (4\%) for about 2.5-5 hours then washed with tap water till neutralizing. The second stage proceeded by bleaching the first stage samples with mixture of hydrogen peroxide (2\%), and aqueous solution of sodium hydroxide (2\%) 1:1, for about 3-5 hours with flipping over from time to time at ambient room temperature, and then washed with tap water till neutralizing.

As we will see in table (3), the best conditions of pulping and bleaching of bagasse according to the highest yield of Wt. remains after bleaching \% is exp. no. (4). 
Ali, Hoda., et al.

Table (3): bleaching conditions of bagasse

\begin{tabular}{|c|c|c|c|c|}
\hline $\begin{array}{l}\text { Exp. } \\
\text { No. }\end{array}$ & $\begin{array}{l}\text { Bleaching 1st. } \\
\text { step }\end{array}$ & $\begin{array}{l}\text { Bleaching } \\
\text { 2nd. step }\end{array}$ & $\begin{array}{c}\text { Wt. remains } \\
\text { after bleaching } \\
\%\end{array}$ & Observ. \\
\hline 1 & $3 \mathrm{hrs}$. & $5 \mathrm{hrs}$. & 27.18 & $\begin{array}{c}\text { Unbulky sample } \\
\text { has some } \\
\text { unchanged parts, } \\
\text { has buff color }\end{array}$ \\
\hline 2 & 4 hrs. & 5 hrs. & 29.26 & $\begin{array}{c}\text { Bulky sample, } \\
\text { much whiter than } \\
\text { exp.3 }\end{array}$ \\
\hline 3 & 4 hrs. & 5 hrs. & 31.31 & Bulky sample \\
\hline 4 & $4 \mathrm{hrs}$. & $5 \mathrm{hrs}$. & 33.9 & \\
\hline 5 & $3 \mathrm{hrs}$. & 3 hrs. & 23.38 & \\
\hline 6 & $2.5 \mathrm{hrs}$. & 3 hrs. & 21.0 & \\
\hline 7 & 4 hrs. & $3 \mathrm{hrs}$. & 23.62 & \\
\hline$\Lambda$ & $5 \mathrm{hrs}$. & $5 \mathrm{hrs}$. & & \\
\hline$\Lambda_{-a}$ & & & 17.05 & Little bulky \\
\hline A-b & & & 17.75 & Little bulky \\
\hline$\Lambda_{-c}$ & & & 16.96 & Little bulky \\
\hline$\Lambda_{-d}$ & & & 18.38 & $\begin{array}{l}\text { Powder, little darker } \\
\text { than exp.no. } 8 \text {-e }\end{array}$ \\
\hline$\Lambda_{-e}$ & & & 21.47 & $\begin{array}{c}\text { Powder, much } \\
\text { darker than exp.no } \\
\text { 8-d }\end{array}$ \\
\hline
\end{tabular}

Tests on bleached raw materials: These tests are carried out to distinguish the $\alpha$-cellulose content according to 18 's factory sheet.

1- $\alpha$-cellulose content: $10 \mathrm{ml}$ of aqueous solution of sodium hydroxide $\left(17.8 \%\right.$ ) is added to $2 \mathrm{gm}$. (wt) of a dried sample (16 hrs in $105^{\circ} \mathrm{c}$ drying oven) in $25 \mathrm{ml}$ beaker, stir fast till the sample absorb the soda solution

Vol.(50); Iss.(10); No.(4); Oct. 2021 
then let for $20 \mathrm{~min}$. exactly. Stop reaction by using $50 \mathrm{ml}$ of distilled water, filter in a pre-weighted dried porcelain gouch $1 \mathrm{G} 3(\mathrm{w})$, wash with distilled water till neutralizing, wash with acetic acid 2-3 times, wash with boiled distilled water till neutralizing, then put the gouch in $105^{\circ} \mathrm{c}$ drying oven for $16 \mathrm{hrs}$, let cool and reweight the gouch with sample (w1)

$\alpha$ - cellulose content $(\%)=[(\mathrm{w} 1-\mathrm{w}) / \mathrm{wt}] \times 100$

2- Degree of polymerization:: Dissolve $0.82 \mathrm{gms}$ of dried sample (16 hrs in $105^{\circ} \mathrm{c}$ drying oven) in $25 \mathrm{ml}$ of copper ethylene diamine in a dark brown sealed bottle ,after using nitrogen gas to replace oxygen in the bottle, let the bottle on shaker till dissolve, then apply solution to Abel hood device , measure the time taken by the solution to pass throw the device ,compare time with the polymerization -time table to explain time in a polymerization degree .

3-Whiteness degree: Take the reading of the color tester device LFM1 (B Raive instruments, DR Lunge. weib standard) after calibration by whitness standard slice with optical standard filter $\mathrm{Y}(\mathrm{Ry}=79.3)$.

4-Nitration of cellulose: According to Urbanski, (1965): The NC was being prepared and stabilized under synthesis conditions required to obtain NC soluble in alcohol ester. The chosen raw materials cellulose was nitrated with mixed acid containing $17 \% \mathrm{H} 2 \mathrm{O}$, nitric acid and 
sulphoric acid, after the reaction was completed, the residue was filtered in a vacuum filter, stabilized and dried.

\section{Characterization of produced nitrocellulose: According to Bofors,(1960)}

1-Nitrogen content: Nitrogen of nitrates is determine in the nitrometer by Lunge-Senderholm's method. By shaking a nitrate solution with excess sulphuric acid in the presence of mercurey, nitrogen is quantitatively disengaged as nitricoxide (NO).The pressure exerted by the gas in a given volume is measured. The weight of NO laberated can then be calculated as following :\% of Nitrogen=.0627.v. $(\beta \pm p) .273 /$ w. 760 . $(273+\mathrm{t})$

Where $\mathrm{v}=$ volume of the reading tube in $\mathrm{ml}$.

$\mathrm{B}=$ barometric pressure in $\mathrm{mm}$. $\mathrm{Hg}$. Corrected to $0^{\circ} \mathrm{C}$.

$p=$ pressure difference between air and gas inside the reading tube, in $\mathrm{mm}$. Hg. $(+$ in the formula, if the gas shows excess pressure, in relation to the air, itherwise-).

$\mathrm{w}=$ weight of sample, $\mathrm{t}=$ tempreatuer in ${ }^{\circ} \mathrm{C} ., .0627 . \mathrm{v} .273 / 760$ is constant $=\mathrm{k}$

So $\%$ of Nitrogen $=k .(\beta \pm p) / w .(273+t)$

2-Viscosity : Viscometer by Ostwald-Bohme

-Pour out $1.0 \mathrm{gm}$ of dried nitrocellulose into the mixing cylinder equipped with a cork. Add $120 \mathrm{ml}$. of a mixture of $93 \%$ acetone and $7 \%$

\footnotetext{
Vol.(50); Iss.(10); No.(4); Oct. 2021

ISSN $1110-0826$

Online ISSN 2636-3178
} 
water, place the cylinder in the shaking apparatus till dissolving, and let it settle 2 hours. In another measuring cylinder pour so much of the solution that is immersed on the level with 10 by applying vacuum draw the solution above mark A, record the time by the liquid to drop from mark A to mark B. repeat determination by using distilled water at the same temperature.

Viscosity = efflux time of the solution, in sec. / efflux time of the water, in sec.

\section{RESULTS AND DISCUSSION}

The yield of $\alpha$-cellulose\%, Degree of whiteness, and Degree of polymerization are summarized in table (4)

Table (4): Results of tests on bleached bagasse

\begin{tabular}{|c|c|c|c|c||}
\hline $\begin{array}{c}\text { Exp. } \\
\text { No. }\end{array}$ & $\begin{array}{c}\boldsymbol{\alpha} \text { - } \\
\text { cellulose\% }\end{array}$ & $\begin{array}{c}\text { Degree of } \\
\text { whiteness }\end{array}$ & $\begin{array}{c}\text { Degree of } \\
\text { polymerization }\end{array}$ & Observation \\
\hline \hline 1 & 95.70 & 71.80 & Didn't dissolve & \\
\hline 2 & 97.19 & 70.50 & Didn't dissolve & \\
\hline 3 & 90.86 & 73.10 & Didn't dissolve & \\
\hline 4 & 95.27 & 70.80 & Didn't dissolve & \\
\hline 5 & 88.40 & 70.20 & Didn't dissolve & \\
\hline 6 & 86.95 & 70.90 & Didn't dissolve & \\
\hline 7 & 82.85 & 73.90 & Didn't dissolve & \\
\hline$\wedge_{-} \mathrm{a}$ & 91.47 & & Didn't dissolve & without bleaching \\
\hline$\wedge_{-} \mathrm{b}$ & 94.19 & & Didn't dissolve & without bleaching \\
\hline$\wedge_{-} \mathrm{c}$ & 93.01 & & Didn't dissolve & without bleaching \\
\hline$\wedge_{-} \mathrm{d}$ & 93.63 & & Didn't dissolve & without bleaching \\
\hline$\wedge_{\mathrm{e}-1}$ & 95.88 & & Didn't dissolve & without bleaching \\
\hline$\wedge_{\mathrm{e}-2}$ & 80.17 & & Didn't dissolve & $\begin{array}{c}\text { a-cellulose\% after } \\
\text { bleaching }\end{array}$ \\
\hline \hline
\end{tabular}


From table (4), the best results of $\alpha$-cellulose $\%$ is exp. no. (2)

Nitration conditions for bagasse cellulose is $(1 \mathrm{gm}$. Of bleached sample: $50 \mathrm{gm}$. Of mixed nitration acid).

Nitration has done on some experiments of bagasse, not all of them

Table (5): Results of nitration of bleached bagasse

\begin{tabular}{|c|c|c|c|c|}
\hline $\begin{array}{c}\text { Exp. } \\
\text { No. } \\
\end{array}$ & $\begin{array}{c}\text { Nitrogen } \\
\% \\
\end{array}$ & $\begin{array}{c}\text { Relative } \\
\text { viscosity } 1 \% \\
\end{array}$ & $\begin{array}{l}\text { Wt.\% remaining } \\
\text { after Nitration }\end{array}$ & observation \\
\hline 1 & 10.99 & 1.30 & 73.09 & $\begin{array}{c}\text { The sample has woody } \\
\text { impurities }\end{array}$ \\
\hline 2 & 11.40 & 1.74 & $\begin{array}{l}\text { The wt. slightly } \\
\text { increased }\end{array}$ & $\begin{array}{c}\text { The sample has fibers didn't } \\
\text { nitrated }\end{array}$ \\
\hline 4 & 11.19 & 4.44 & 100 & $\begin{array}{c}\text { Solution of viscosity has } \\
\text { woody impurities }\end{array}$ \\
\hline 5 & 10.98 & 1.75 & $\begin{array}{c}\text { The wt. slightly } \\
\text { increased }\end{array}$ & $\begin{array}{l}\text { The sample has less } \\
\text { impurities than exp. } 4\end{array}$ \\
\hline 7 & 10.62 & 1.25 & 57.11 & $\begin{array}{c}\text { The sample has yellow color } \\
\text { and impurities }\end{array}$ \\
\hline $8-\mathrm{a}$ & Less than 7 & 1.09 & 32.71 & \\
\hline $8-b$ & 10.23 & 1.09 & 33.0 & \\
\hline $8-\mathrm{c}$ & 9.85 & 1.09 & 29.0 & \\
\hline $8-d$ & 9.86 & 1.09 & 33.50 & \\
\hline 8 -e & 10.23 & 1.14 & 57.86 & \\
\hline
\end{tabular}

From table (5), the best results of nitration according to nitrogen content $\%$ is exp. no. (2).

Wt.\% remaining after Nitration (slightly increased) is a normal phenomena due to the reaction of nitration.

From the above tables, bagasse gives high results of $\alpha$-cellulose $\%$ and good respond to nitration . 
Cellulose and nitrocellulose of exp. no.(2) is proved by using IR spectroscopy, and proton NMR spectroscopy as will show bellow.

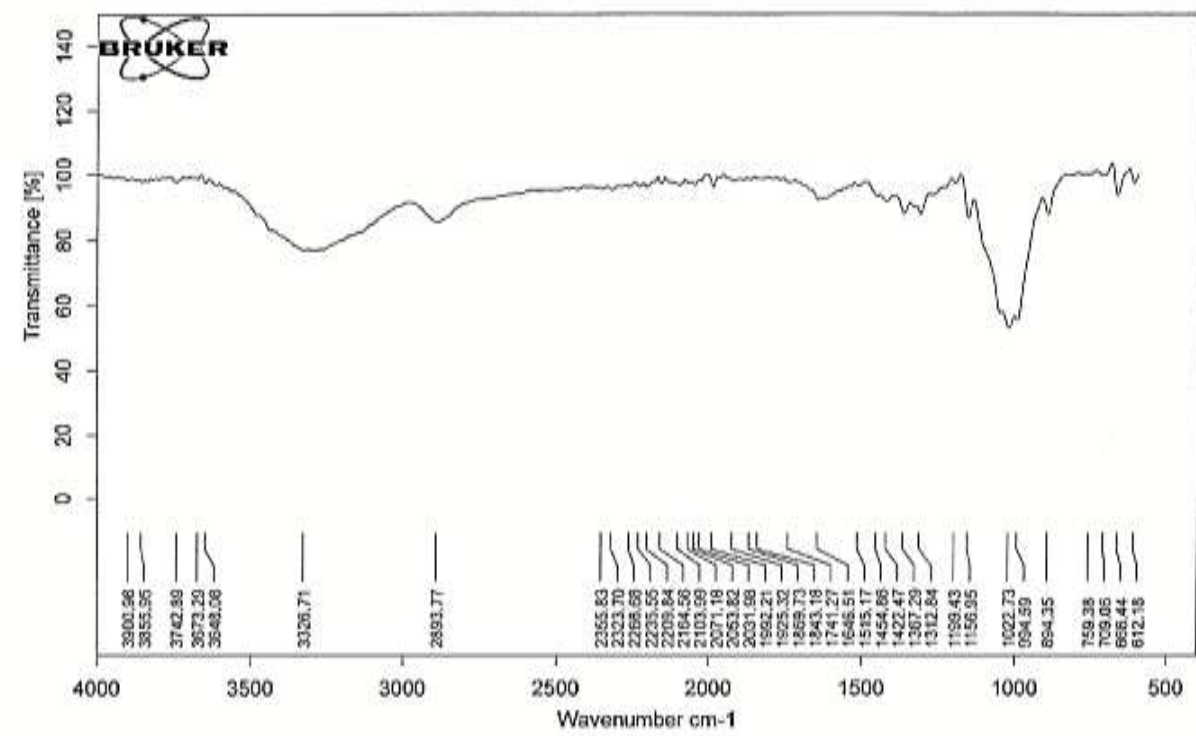

Fig (1): Infra Red (IR) Spectroscopy proves the St. of cellulose from bleached bagasse exp. no.(2)

The structure of cellulose and nitrocellulose, which taken from bagasse, exp. no. 2, have been proven by IR spectroscopy and proton NMR, as follows: 


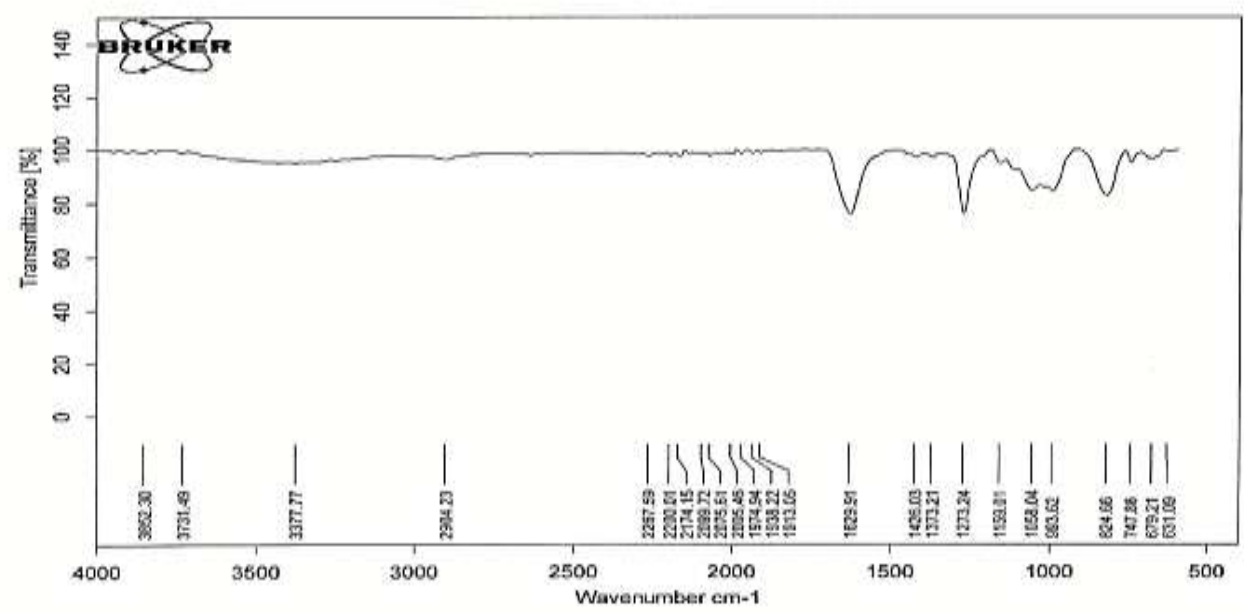

Fig (2): Infra Red (IR) Spectroscopy proves the St. of nitrocellulose from bleached bagasse exp. no.(2)

IR spectra of the bleached bagasse cellulose and nitrocellulose are shown in Figure 1, 2.

A comparison between the IR spectra of the bleached bagasse cellulose and NC shows that stretching peak of hydroxyl lgroups on the glucose rings near $3500 \mathrm{~cm}-1$ was greatly reduced, which signifies that the hydroxyl groups were partially substituted by the nitryl group. After nitration, the spectrum clearly shows the typical signal pattern sought for the NC sample from exp. no. 2. The right half of the spectrum below $1670 \mathrm{~cm}-1$ contains five characteristic peaks: two sharp intense peaks observed at around 1660 and $1280 \mathrm{~cm}-1$ corresponding to the $\mathrm{NO} 2$ asymmetric and symmetric stretching, respectively; a slightly broader, intense peak at around $832 \mathrm{~cm}-$

Vol.(50); Iss.(10); No.(4); Oct. 2021 
1 assigned to the $\mathrm{ONO}_{2}$ stretching; a less intense peak observed at about 748 $\mathrm{cm}^{-1}$ corresponding to the $\mathrm{O} \mathrm{NO}_{2}$ asymmetric bending, while the band at about $684 \mathrm{~cm}^{-1}$ is attributed to the $\mathrm{O} \mathrm{NO}$ symmetric bending. In the vicinity of $1200-950 \mathrm{~cm}^{-1}$ are a few medium-intensity peaks corresponding to different vibrations of the $\mathrm{CO}$ group.Overall, the IR spectrum of the bagasse $\mathrm{NC}$ exhibits all the peaks representative of nitro groups.

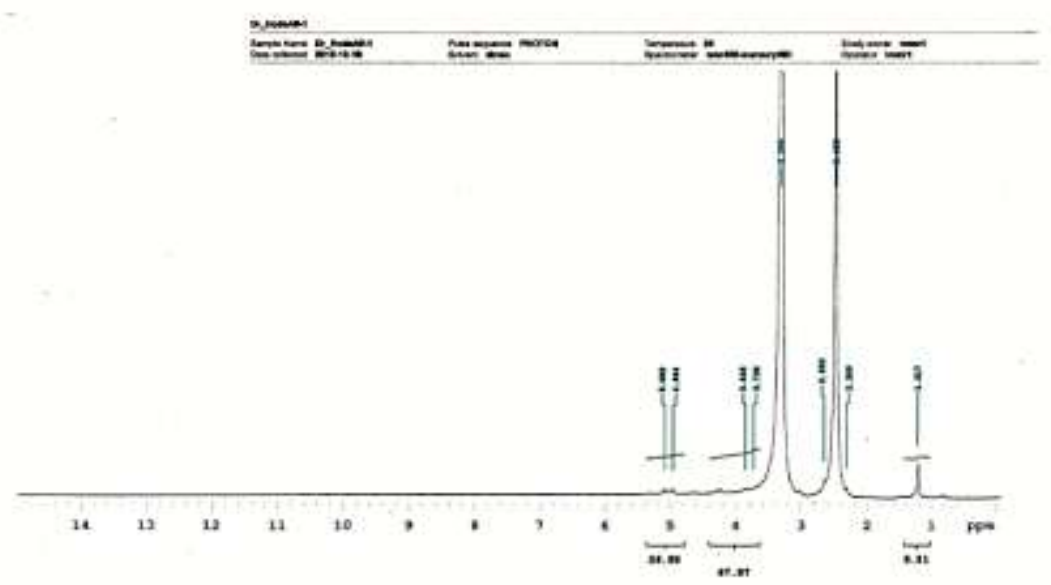

Fig(3): Proton Nuclear Magnetic Resonance (NMR) proves the St. of cellulose from bleached bagasse exp. no.(2) 


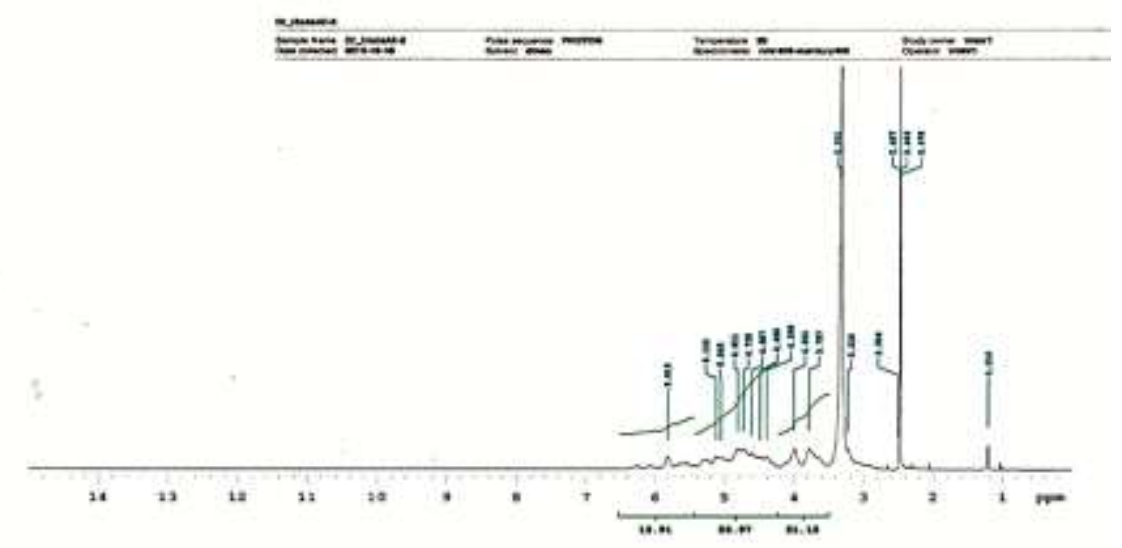

Fig (4): Proton Nuclear Magnetic Resonance (NMR) proves the St. of nitrocellulose from bleached bagasse exp. no.(2)

The ${ }^{13} \mathrm{C}$ NMR spectrum of the bleached bagasse NC exhibits a chemical lshift at $\mathrm{d}=70.9 \mathrm{ppm}$, suggesting that most C-6hydroxyl groups were esterified. Along with that, the C-3and C-2 hydroxyl groups were also substituted by nitro groups, and their peaks appeared at $\mathrm{d}=83.0 \mathrm{ppm}$ and $\mathrm{d}=84.4 \mathrm{ppm}$. The peak of the C-6 nitro groups is stronger than those of the C-2 and C-3 nitro groups, indicating that the hydroxyls at C-2 and C-3 were only partially esterified and esterification chiefly occurred on the C-6 hydroxyl groups.

A comparison of the 13C NMR spectrum of the bleached bagasse NC with earlier reported cotton NCs shows the matching of most chemical shifts typical of 6-mono-nitrocellulose, 2,6- dinitrocellulose,3,6dinitrocellulose, and2,3,6-trinitrocellulose. It is thus evident that the bagasse

Vol.(50); Iss.(10); No.(4); Oct. 2021 
NC holds both2, 6-di-,3, 6-di-andtri-substitutedmoieties of the tglucopyranose ring of the cellulose macro molecule.

The findings on the synthesis of NC from bagasse are quite promising.

\section{CONCLUSION}

This study recommended the uses of cellulosic content of agriculture waste especially bagasse as a raw material for synthesis nitrocellulose instead of cotton linter for a cheap raw material and protection of environmental impact of raw materials.

\section{REFRENCES}

Abdel-Ala, A. R. M.; Abdel. Esam, A.M.; ahmed, O.; El- Kady, M. and Nada, A.M.A. (2003): Cations Exchangers resiens from sunflower stalks 2- in fraread sunflower stalks 2- Infrared Spectroscopy, 7th Arab Interaction conferences on Polymer Science and Technology 135

Abou Hussein, S. D. and Sawan, O.M: Agricultural Waste as One of the Environmental Issues in Egypt (A Case Study) .Journal of Applied Sciences Research, 6(8): 1116-1124, INSInet Publication The Utilization of Agricultural Waste Recycling Unit, Egyptian Environmental Affairs Agency, Ministry of state for Environment Affairs, (2010). 
Afifi, S.Y.; Elshek, M.A.M. E.; El-Kady, M. and Ahdy, M.A: Recovery of Some Valuable Elements from El-Garra, El-Mamara Sulfate Leach LiqureLeach Liqures by modified Lignocellulosic Cotton Sulfate Leach Liqure Stalk., Journal of Nuclear Science and Application, 39 (2), (2006).

Bofors, N. AB.(1960): Analytical methods for powders and explosives, pages $75-163$

Egyptian Environmental Affairs Agency. (2003): land use control and growth options for environmentally sensitive areas

El- Kady, M. (2001): 6th Arab international conference on Polymer Science and technology 162, Sept 1-5

El- Kady, M.; Salama, M.A.; Mansour, O.Y. and flefel, E.M. (2001): New method of flow up the Crafting of Different monomers onto cellulose xanthate (Part1). 6t5h international canfernce on chemistry and its Role in Develop nent (ICCRD) 3/12, Mansoura April 17-20.

El- Kady, M.; Salama, M.A.; Mansour, O.Y. and flefel, E.M. (2001): New method of flow up the grafting of different monomers onto Cellulose Xanthate (part-2)

El- Kady, M.;El-Adly, R.A.; Khall, M.M.H. and Abdel Wahed, A.A. (2014): Novel Utilization of Rice Straw in the Proclaction of Lubricating greases Accepted in J.Env.Sci.

El- Kady, M.; ElAdly, R.A.; Khalil, M.M.H.; Abdel Wahed, A.A.): Novel utilization of Rice straw in the production of lubricating grease. Accepted in Journal, Envir. Res. (ASU), (2016).

El-Hoshaudy, A.N; Desouky, S.E.M M; El- Kady,M.; Al Sabagh, A.M.; Betiha, M.A. and Mahmoud, S: Accepted in International Journal of Polymers Science Volum 2015,.(2015) 
Gismatulina, Y.A; Budaeva, V. V. and Sakovich,G. V. (2018): nitrocellulose synthesis from Miscanthus cellulose, propellants, explosives, pyrotechnics 43:96-100

Hassan, H. B. A.; el Gebaly, M. R.; Abdul Ghani, S.S. and Hussein, Y. M.M: An Economic Study of Recycling Agricultural Wastes in Egypt. Middle East Journal of Agriculture Research, 3(3): 592608, ISSN 2077-4605, (2014).

Ingram, L. O. ; Doran, J. B. (1995): Conversion of cellulosic materials to ethanol, Author Notes, FEMS Microbiology Reviews, Volume 16,Issue23,February,Pages235,241, https://doi.org/10.1111/j.157 4-6976.1995.tb00170.x

Khezami, L.; Chetouani,A.; Taouk,B. and Capart, R.(2005):Production and characterisation of activated carbon from wood components in powder: Cellulose, lignin, xylan t - Powder Technology, 157 (13), 48-56

Mansour,O.Y; El- Kady, M.; Salama, M.A. and flefel, E.M.(2001): Grafting Copolymerization of some Vinyl Monomer onto cellulose Xanthate (Part-1), E.M.E, 6th Arab Interaction conferences on Polymers Science and Technology (PN 13), 63 Sept, 1-5

Nada, A. M.A.; El- Kady, M.; Abd El-Sayed, E.A. and Amine f. M. (2009): Preparation and characterization of microcrystalline cellulose \{Mec]. Bio resource 4 (4) 1359.

Nada, A. M.A.; Mohamed, Y.; El-Kady, M. and Fekry, H.M.(2007): Synthesis and characterization of Grafted Cellulose for use water and metal sorption. Bio resources 3 (1) 46-59.

Saleh, R. M.; Mahmoud A; Hewehy, M. Y.; El-Kady, M.; Khalil, M. H.; Ali , M. E.M.( 2019 ): Corncob Driven Biochar for adsorption of water pollutants Accepted in environmental scientific research Ain shams University 
Stefanidis, S. D. ; Kalogiannis, K. ; Eleni F.I.; Petros, C.M.M.; Angelos, A.P.; Lappas, A.: A study of lignocellulosic biomass pyrolysis via the pyrolysis of cellulose, hemicellulose and lignin.Journal of Analytical and Applied Pyrolysis, Volume 105, January, Pages 143-150, (2014).

Taha, S. M.; Amer, M. E. ; Elamarsafy, A. E. and El- Kady, M.(2014): Adsorption of 15 different pesticides on untreated and Phosphoric acid treated heated biochar and Charcoal from water. J. of Environmental Chemica 12 2013-2925.

Urbanski, T. (1965): Chemisry and technology of explosives vol.2, pages 372-392

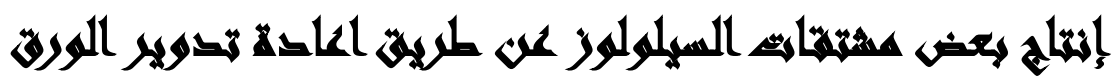 بالمخلفايت اللزراعية}

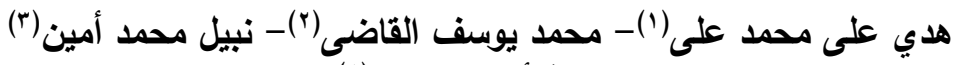

$$
\begin{aligned}
& \text { فاطمة أمين محمود (؛) }
\end{aligned}
$$

( ) طالبة دراسات عليا بكلية الدراسات العليا والبحوث البيئية، جامعة عين شمس ؟ ؟) كلية العلوم،

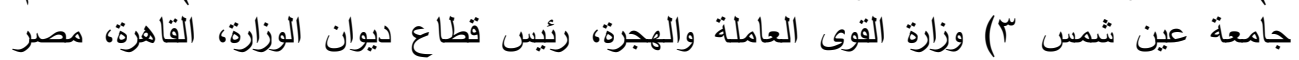
؟) باحث بالمركز القومي للبحوث، جيزة، مصر

\section{varill}

يبحث العالم الان عن بدائل متجددة ورخيصة ليتم استخدامها بالصناعة لتوفر الحماية للبيئة

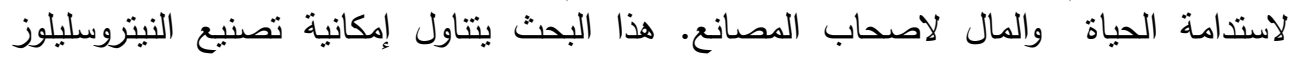

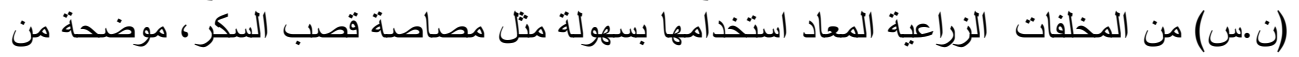

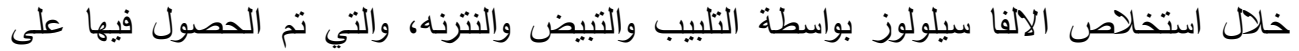

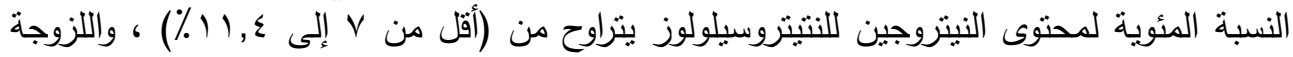

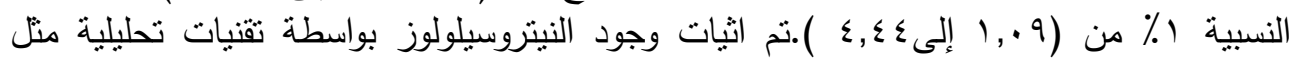


Journal of Environmental Sciences (JES)

Faculty of Graduate Studies and Environmental Research, Ain Shams University

Ali, Hoda., et al.

مطيافية الأشعة تحت الحمراء ، مطيافية الرنين المغناطيسي النووي بالبروتون. وجد أن مصاصة

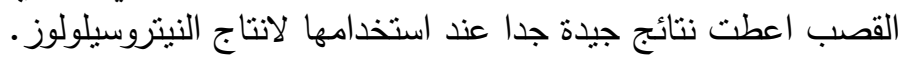

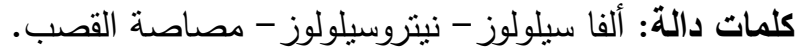

Vol.(50); Iss.(10); No.(4); Oct. 2021

ISSN 1110-0826

Online ISSN 2636-3178 